\title{
Desulfurization of Mach Coal of Balochistan by Leaching Method
}

\author{
Faisal Mushtaq ${ }^{a^{*}}$, Asadullah ${ }^{\mathrm{b}}$, Asfandyar Khan ${ }^{\mathrm{c}}$, Abdul Waheed ${ }^{\mathrm{f}}$, Syed Haseeb Sultan ${ }^{\mathrm{b}}$, Ghulamullah \\ Kakar $^{\mathrm{d}}$, Gohram Khan ${ }^{\mathrm{a}}$, Abdul Malik Rehan Abbasi ${ }^{\mathrm{e}}$ \\ ${ }^{a}$ Universiti Teknolgi Malaysia, Skudai, Johor Bahru, Johor, Malaysia. \\ ${ }^{\mathrm{b}}$ Prince of Songkla University, Hat Yai, Songkhla, Thailand. \\ ${ }^{\mathrm{c}}$ FFC Limited, Rawalpindi, Pakistan \\ ${ }^{\mathrm{d}}$ University of Malaya, Kuala Lumpur, Malaysia. \\ e Technical University of Liberec, Studentska, Liberec, Czech Republic. \\ ${ }^{\mathrm{f}}$ SEME, NUST, Islamabad
}

*Corresponding author e-mail: faisalqta1977@gmail.com

\begin{abstract}
Coal desulfurization prior to usage is frequently subjected to preprocessing to achieve clean fuel and reduce environmental impacts. In this study, desulfurization of Mach coal of Balochistan was investigated with different leaching solvents. The solvents used are $\mathrm{NaOH}$ and $\mathrm{HNO}_{3}$. Effects of particle size and solvent weight $\%$ on sulfur removal were studied, whereas the leaching temperature and the agitation time were kept constant. Desulfurization experiments were carried out for 12 samples of different composition based on different particle size and solvent weight $\%$. Significant reduction in Sulfur was attained when the coal particle size of 10 Mesh was used. The results indicated that Sulfur reduction was highest of $44.88 \%$ when $\mathrm{HNO}_{3}$ was used as compare to $\mathrm{NaOH}$ which gave maximum Sulfur reduction of $\mathbf{2 4 . 7 2 \%}$. Sulfur recovery was found to increase with increasing solvent concentration. Decreased desulfurization was observed with larger coal particle size of 6 Mesh. Leaching process using variable solvent concentration was found effective and could be inexpensive for desulfurization of coal.
\end{abstract}

Keywords- Desulfurization, Coal, Solvent Leaching, $\mathrm{HNO}_{3}, \mathrm{NaOH}$

Date Received: $27-10-2020$

Date Accepted: 06-11-2020

Date Published: 08-06-2021

\section{INTRODUCTION}

\section{$\mathrm{I}_{\mathrm{n}}$}

Pakistan, the primary energy supply mainly comes from

coal and natural gas resources. The energy demand of the country is growing and the expected growth rate over the past five years was estimated at $7.4 \%$ per annum [1]. Coal is considered to be a major source of world energy. Commercial and financial growth in the developing countries is leading to increase in the demand for energy. Over the recent years, the energy crisis of natural gas and rising prices of crude oil, the country energy industries are focusing on speeding up the development of coal based chemical industries. As an alternative fuel, the coal based chemical industry can make a substantial impact in the development of some of the developing countries [2]. Concerning environmental issues in the next twenty years, the energy resources may reduce the pollution caused by the burning of coal. It will also lessen dependence on oil and gas as energy source. In other words, due to being readily available and inexpensive the demand in the use of coal will increase [3]. During the burning of coal, nearly $90 \%$ of the sulfur in the form of sulfur oxides $\left(\mathrm{SO}_{2}\right)$ is released into the atmosphere if not removed before utilization. Furthermore, the release of $\mathrm{SO}_{2}$ is considered one of the main source of acid rain, which leads to the acidification of soils, deforestation and surface water contamination [4]. Therefore, the progress in the coal fired capacity without desulfurization can lead to increasing fear about environmental concerns, such as increased emissions of $\mathrm{SO}_{2}$, particulates, and nitrogen oxides $\left(\mathrm{NO}_{\mathrm{x}}\right)$ and trace elements.

Pakistan has appeared to be one of the leading country in coal resources after the discovery of huge resources of lignite coal located in Sindh and listed seventh in the top twenty countries of the world [5]. It is important to note that the share of coal in India is as high as $54.5 \%$ in the total energy mix [6]. Despite the presence of huge reserves of coal, Pakistan is still facing energy crisis because its coal potential is not being explored. To meet the future requirements of the country with indigenous resources, local exploration would have to be strengthened to accelerate the share of coal from 5 to $25 \%$ by 2021 [7]. The global $\mathrm{SO}_{2}$ emission comes mainly from coal utilization where coal fired power plants is considered as a major contributor. Pakistani coal owns high sulfur and ash contents which limit its utilization in several industrial applications, both in coals are unsuitable for their effective use in liquefaction, gasification, combustion, and carbonization purpose [8]. Combustion of high sulfur content coal in thermal power plants release significant amount of $\mathrm{SO}_{2}$ which is due to the oxidation of sulfur present in coal [9]. Sulfuric acid is formed due to the oxidation of the 
oxides present in the sulfur which may further result in the acid rain.

The sulfur exists in organic and inorganic forms in the coal. The inorganic forms of the sulfur present in coal are usually sulfates and sulfides, where pyrite being as the major inorganic sulfur in most coals. The inorganic sulfur components in the coal are determined by the analytical methods and several commercial methods exist for the removal of much of the inorganic sulfur from the coal [10], [11]. The organic sulfur present in coal is the macromolecular assemblies' structures and are not readily analyzed or separated without the destruction of macromolecular network. A variety of analytical methods have been developed for determining the inorganic sulfur as a functional group of the coal. Some of these are destructive tests depending on the oxidation to $\mathrm{SO}_{2}$, catalytic reduction to $\mathrm{H}_{2} \mathrm{~S}$ or pyrolysis. However, numerous nondestructive X-ray methods now offer to measure sulfur types (thiophenic, aliphatic, aromatic) directly.

In Pakistan, the total sulfur content identified in the coal from major coal fields are in the range of $0.5-10 \mathrm{Wt} . \%$ and high in ash content [12]. Consumption of such high ash and sulfur contents coal raises several environmental concerns. It is therefore essential to desulfurize the coal before being utilized [13]. Various physico-chemical and biological processes are used for the desulfurization of coal. Physical methods, such as froth flotation and magnetic separation can only eliminate a part of pyritic sulfur but cannot reduce organic sulfur species. The microbial method mostly used $T$. thiooxidans and $T$. ferrooxidans bacteria, which only work with the removal of inorganic sulfur and cannot reduce organic portion of sulfur present in coal [14].

Present work aims to desulfurize the Pakistani coal from Mach Balochistan by using chemicals under various solid loading, particle size and acid/alkali concentrations. The temperature and the process residence times were kept constant.

\section{MATERIALS AND MethodS}

Coal samples collected from different mines at Mach coal fields located in Balochistan province of Pakistan on random basis. Initially the coal samples were placed inside the oven at appropriate temperature for removal of excess moisture before size reduction. Pure solvents of analytical grade were purchased from Merck Aldrich and used.

\section{A. Proximate analysis}

Proximate analysis of the coal sample was calculated based on the standard ASTM method [15]. The total sulfur in the coal was determined by quantitative technique of "dynamic flash combustion" [16]. Table 1 shows the complete results of proximate analysis. The Sulfur content of the Mach coal is high which is very important to be treated before utilizing in the industry.

Table 1: Composition of Mach Coal

\begin{tabular}{|l|l|}
\hline Component & Composition \\
\hline Ash \% & 11.47 \\
\hline Moisture \% & 8.52 \\
\hline
\end{tabular}

\begin{tabular}{|l|l|}
\hline Volatile matter \% & 34.60 \\
\hline Fixed carbon \% & 40.52 \\
\hline Sulfur \% & 6.15 \\
\hline Calorific Value(Btu/lb) & 11,736 \\
\hline
\end{tabular}

\section{B. Size reduction and size distribution}

Jaw crusher was used to reduce the size of coal upto the appropriate level. Vibratory Sieve shaker was used for size distribution of coal to 6 and 10 mesh numbers.

\section{Preparation of different concentration of $\mathrm{HNO}_{3} / \mathrm{NaOH}$ solutions}

Three different concentrations (wt. \%) of each solvent were prepared using standard dilution method [17]. Solutions were prepared by dissolving $5 \mathrm{gm}, 15 \mathrm{gm}$, and $30 \mathrm{gm}$ of $\mathrm{NaOH}$ and $\mathrm{HNO}_{3}$ in 100 milliliter of distilled water and mixed thoroughly.

\section{Methodology}

The stepwise methodology of the desulfurization of coal can be seen at Fig. 1. Equal amount of crushed coal samples were placed in the air tight bags. Different solutions of solvents were prepared by diluting and mixing the coal in $\mathrm{NaOH}$ and $\mathrm{HNO}_{3}$ on electric heating plate with magnetic stirrers. The prepared coal samples were treated with different concentration of $\mathrm{NaOH}$ and $\mathrm{HNO}_{3}$ solvents at $90{ }^{\circ} \mathrm{C}$ and 30 minutes residence time.

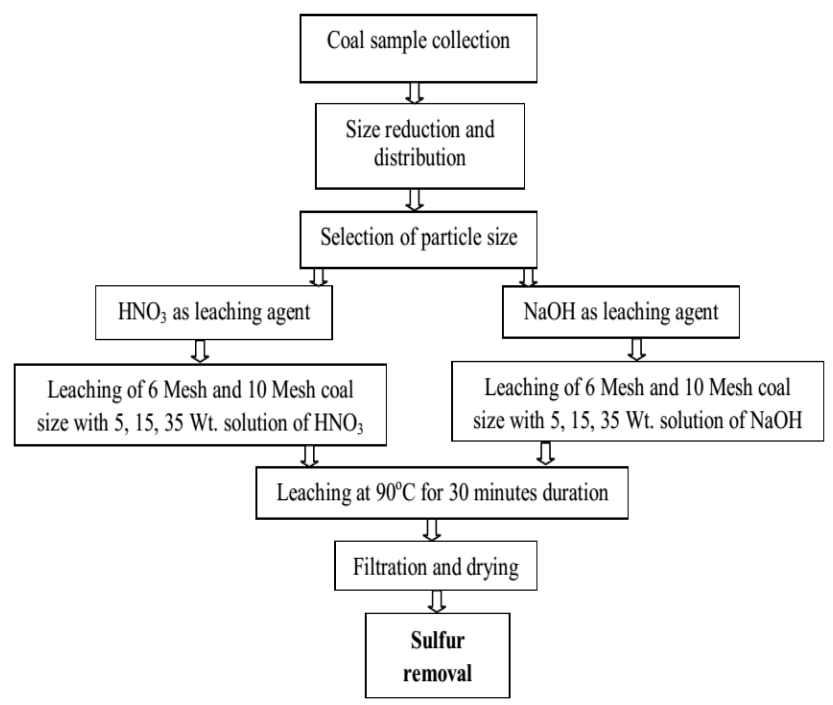

Figure 1. Methodology of this study

\section{RESULTS AND DISCUSSION}

The details of prepared samples under various process conditions are given in the Table 2-4.

Table 2. Process parameters

\begin{tabular}{|l|l|l|l|l|l|l|}
\hline Sample & $\begin{array}{l}\text { Acid/ } \\
\text { Alkali }\end{array}$ & $\begin{array}{l}\text { Particle } \\
\text { size, } \\
\text { Mesh }\end{array}$ & $\begin{array}{l}\text { Weight } \\
\text { of Coal } \\
(\mathbf{g})\end{array}$ & $\begin{array}{l}\text { Weight } \\
\% \\
(\mathbf{g} / \mathbf{1 0 0 m l})\end{array}$ & $\begin{array}{l}\text { Temp. } \\
\left({ }^{\circ} \mathbf{C}\right)\end{array}$ & $\begin{array}{l}\text { Time } \\
(\mathbf{m i n} .)\end{array}$ \\
\hline 1 & $\mathrm{HNO}_{3}$ & 6 & 10 & 05 & 90 & 30 \\
\hline
\end{tabular}




\begin{tabular}{|l|l|l|l|l|l|l|}
\hline 2 & $\mathrm{HNO}_{3}$ & 6 & 10 & 15 & 90 & 30 \\
\hline 3 & $\mathrm{HNO}_{3}$ & 6 & 10 & 30 & 90 & 30 \\
\hline 4 & $\mathrm{HNO}_{3}$ & 10 & 10 & 05 & 90 & 30 \\
\hline 5 & $\mathrm{HNO}_{3}$ & 10 & 10 & 15 & 90 & 30 \\
\hline 6 & $\mathrm{HNO}_{3}$ & 10 & 10 & 30 & 90 & 30 \\
\hline 7 & $\mathrm{NaOH}$ & 6 & 10 & 05 & 90 & 30 \\
\hline 8 & $\mathrm{NaOH}$ & 6 & 10 & 15 & 90 & 30 \\
\hline 9 & $\mathrm{NaOH}$ & 6 & 10 & 30 & 90 & 30 \\
\hline 10 & $\mathrm{NaOH}$ & 10 & 10 & 05 & 90 & 30 \\
\hline 11 & $\mathrm{NaOH}$ & 10 & 10 & 15 & 90 & 30 \\
\hline 12 & $\mathrm{NaOH}$ & 10 & 10 & 30 & 90 & 30 \\
\hline
\end{tabular}

Table 3. Removal of Sulfur with different particle size and $\mathrm{HNO}_{3}$ concentration

\begin{tabular}{|l|l|l|l|l|l|}
\hline $\begin{array}{l}\text { Chemical } \\
\text { Agent }\end{array}$ & $\begin{array}{l}\text { Particle } \\
\text { size, } \\
\text { Mesh }\end{array}$ & $\begin{array}{l}\text { Weight } \\
\%\end{array}$ & $\begin{array}{l}\text { Initial } \\
\text { Sulfur } \\
\%\end{array}$ & $\begin{array}{l}\text { After } \\
\text { Leaching } \\
\text { Sulfur \% }\end{array}$ & $\begin{array}{l}\text { Sulfur } \\
\text { Reduced } \\
\%\end{array}$ \\
\hline $\mathrm{HNO}_{3}$ & 6 & 5 & 6.15 & 5.37 & 12.68 \\
\hline $\mathrm{HNO}_{3}$ & 6 & 15 & 6.15 & 5.11 & 16.91 \\
\hline $\mathrm{HNO}_{3}$ & 6 & 30 & 6.15 & 4.77 & 22.44 \\
\hline $\mathrm{HNO}_{3}$ & 10 & 5 & 6.15 & 4.6 & 25.20 \\
\hline $\mathrm{HNO}_{3}$ & 10 & 15 & 6.15 & 4.08 & 33.66 \\
\hline $\mathrm{HNO}_{3}$ & 10 & 30 & 6.15 & 3.39 & 44.88 \\
\hline
\end{tabular}

Table 4. Removal of Sulfur with different particle size and $\mathrm{NaOH}$ concentrations

\begin{tabular}{|l|l|l|l|l|l|}
\hline $\begin{array}{l}\text { Chemical } \\
\text { Agent }\end{array}$ & $\begin{array}{l}\text { Particle } \\
\text { size, } \\
\text { Mesh }\end{array}$ & $\begin{array}{l}\text { Weight } \\
\text { \% }\end{array}$ & $\begin{array}{l}\text { Initial } \\
\text { Sulfur } \\
\text { \% }\end{array}$ & $\begin{array}{l}\text { After } \\
\text { Leaching } \\
\text { Sulfur } \%\end{array}$ & $\begin{array}{l}\text { Sulfur } \\
\text { Reduced } \\
\text { \% }\end{array}$ \\
\hline $\mathrm{NaOH}$ & 6 & 5 & 6.15 & 5.72 & 6.99 \\
\hline $\mathrm{NaOH}$ & 6 & 15 & 6.15 & 5.58 & 9.27 \\
\hline $\mathrm{NaOH}$ & 6 & 30 & 6.15 & 5.39 & 12.36 \\
\hline $\mathrm{NaOH}$ & 10 & 5 & 6.15 & 5.3 & 13.82 \\
\hline $\mathrm{NaOH}$ & 10 & 15 & 6.15 & 5.01 & 18.54 \\
\hline $\mathrm{NaOH}$ & 10 & 30 & 6.15 & 4.63 & 24.72 \\
\hline
\end{tabular}

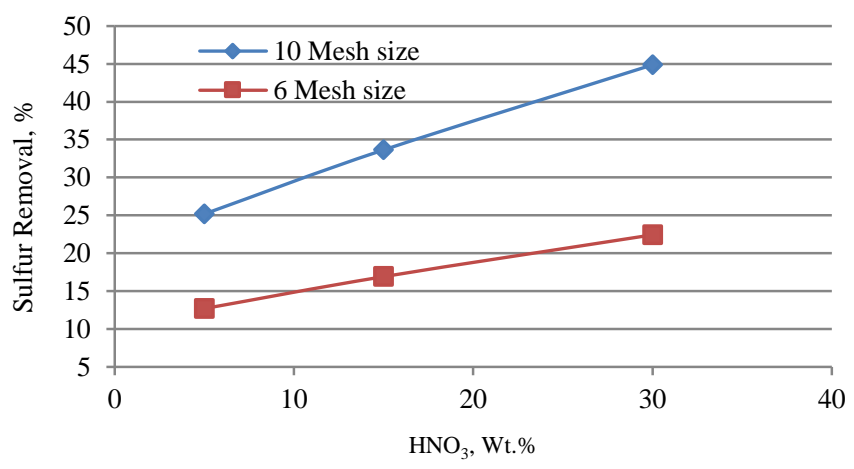

Figure 2. Effects of $\mathrm{HNO}_{3}$ concentration and particle size on Sulfur removal.

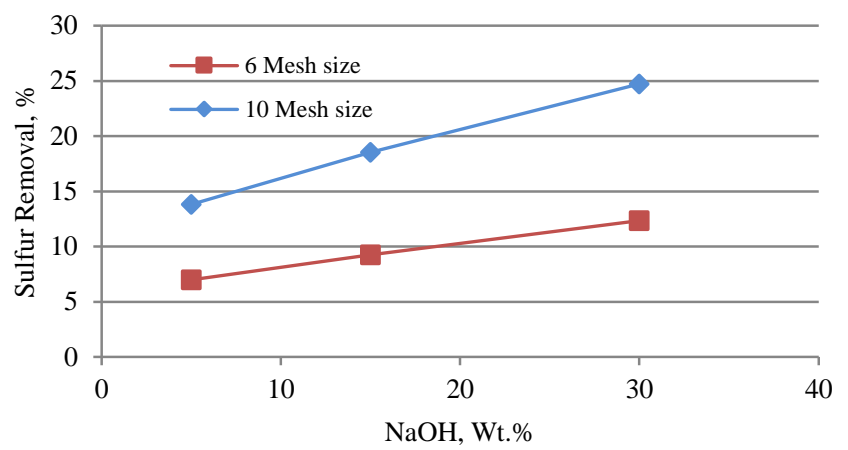

Figure 3. Effects of $\mathrm{NaOH}$ concentration and particle size on Sulfur removal

The effects of solvent concentration of $\mathrm{HNO}_{3}$ and $\mathrm{NaOH}$, and particle size of coal on Sulfur removal can be seen in the Fig. 2 and 3, respectively. The temperature and the residence time of leaching were kept constant. The observed values indicate that the Sulfur removal increases with increase in $\mathrm{HNO}_{3}$ and $\mathrm{NaOH}$ with 6 and 10 Mesh particle size of the coal. The sulfur removal with increasing $\mathrm{HNO}_{3} \mathrm{Wt}$.\% was observed $12.68-22.44 \%$ and $25.20-44.88 \%$ with 6 Mesh and 10 Mesh, respectively. The use of increasing $\mathrm{NaOH}$ Wt.\% resulted in sulfur removal of $6.99-12.36 \%$ and $13.82-24.72 \%$ with 6 Mesh and 10 Mesh, respectively.

Among the tested samples, highest sulfur removal was observed of $44.88 \%$ with 10 Mesh size using $30 \mathrm{Wt} . \% \mathrm{HNO}_{3}$, where it remained maximum of $24.72 \%$ with 10 Mesh size using $30 \mathrm{Wt} . \% \mathrm{NaOH}$. It can also be observed that the percent removal of Sulfur was on higher side for the particle size of 10 Mesh as compared to 6 Mesh with both of the solvents. Similar trends were observed in previous work conducted by [14], [17].

Generally the results indicate that the Sulfur removal increases with decrease in the particle size of the coal, whereas the use of $\mathrm{HNO}_{3}$ as leaching solvent gives much better results in terms of Sulfur reduction compared to the $\mathrm{NaOH}$ solvent. The $\mathrm{NaOH}$ when treated with $\mathrm{H}_{2} \mathrm{~S}_{2}$ gave much better results (54\% Sulfur reduction) in a previous work [18]. The trend of increase in the Sulfur reduction with decrease in coal size may give better results when the particle size of the coal will be reduced to higher mesh number.

\section{CONCLUSION}

In the present work, the effects of $\mathrm{HNO}_{3}$ and $\mathrm{NaOH}$ as leaching agents, concentration of $\mathrm{HNO}_{3}$ and $\mathrm{NaOH}$, and particle size of coal were investigated on $\%$ sulfur removal. The results indicate that the removal of inorganic Sulfur from coal can be optimized with $\mathrm{NaOH}$ and $\mathrm{HNO}_{3}$ (as an oxidizing reagent). The results indicated that the effects of the leaching agent, leaching solvent weight $\%$ and particle size of the coal on the removal of sulfur are significant. Sulfur recovery increases with increasing leaching solvent weight $\%$. Sulfur removal was achieved highest at $44.88 \%$ with 30 wt. $\% \mathrm{HNO}_{3}$ and 10 Mesh coal size. Sulfur removal was on higher side with 10 Mesh size compared to 6 Mesh size coal particles. This higher sulfur removal with smaller particle size of coal can be associated to higher interfacial and contact area between solid and liquid. 
From this study the following finding may be concluded:

- $\mathrm{HNO}_{3}$ desulfurized the coal more efficiently as compared to $\mathrm{NaOH}$.

- The acid/alkali Wt. \% increases the desulfurization removal efficiency.

- The smaller the particle size, the greater the desulfurization efficiency.

- $\mathrm{NaOH}$ was not found effective for greater sulfur removal.

\section{REFERENCES}

[1] T. W. Bank. (2020, 21st Oct.). The World Bank In Pakistan. Available: https://www.worldbank.org/en/country/pakistan/overview

[2] S. R. M. Faisal Rehman, Abdul Mateen Khan, Muhammad Shahzad Zafar, Sharjeel Waqas, "Chemical treatment of coal by alkali using leaching process," Sci. Int, vol. 27, pp. 6137-6140, 2015.

[3] IEA. (2020, $21^{\text {st }}$ Oct.). Coal 2019, Analysis and Forecasts to 2024. Available: https://www.iea.org/reports/coal-2019

[4] M. Z. Duz, A. Saydut, S. Erdogan, and C. Hamamci, "Removal of sulfur and ash from coal using molten caustic leaching, a case study from Hazro fields, Turkey," Energy Exploration \& Exploitation, vol. 27, pp. 391-400, 2009.

[5] NEPRA, "State of Industry Report 2020," National Electric Power Regulatory Authority, Islamabad 2020.

[6] IEA. (2020, 21st Oct.). India 2020, Energy Policy Review. Available: https://www.iea.org/reports/coal-2019

[7] GoP, "Pakistan2025," ed. Islamabad: Planning Comission, Ministry of Planning, Development \& Reform, 2020.

[8] F. Mushtaq, A. Qadeer, F. Mir, and A. Aftab, "Coal Fired Power Generation Potential of Balochistan," Petroleum \& Coal, vol. 54, 2012.

[9] G. Ozbayoglu, "Desulphurization of coal to protect the environment," in Mineral processing and the environment, ed: Springer, 1998, pp. 199-222.

[10] Y. Zhou, B. Albijanic, B. Tadesse, Y. Wang, J. Yang, and $\mathrm{X}$. Zhu, "Desulphurization of coals of different ranks in the presence of slimes by reverse flotation," Energy Reports, vol. 5, pp. 1316-1323, 2019.

[11] W. H. Calkins, "The chemical forms of sulfur in coal: a review," Fuel, vol. 73, pp. 475-484, 1994.

[12] M. S. Malkani, A. M. K. MH, F. Buzdar, and M. Zahid, "Coal Resources of Pakistan: new coalfields," Lasbela University Journal of Science \& Technology, vol. 5, pp. 722, 2016.

[13] S. K. Kawatra and T. C. Eisele, Coal desulfurization: Highefficiency preparation methods: Taylor \& Francis, 2001.

[14]H. Alam, A. Moghaddam, and M. Omidkhah, "The influence of process parameters on desulfurization of Mezino coal by $\mathrm{HNO}_{3} / \mathrm{HCl}$ leaching," Fuel processing technology, vol. 90, pp. 1-7, 2009.

[15]D. ASTM, "D7582-10. Standard Test Methods for Proximate Analysis of Coal and Coke by Macro Thermogravimetric Analysis," in ASTM: West Conshohocken, PA, ed, 2012.

[16] G. Dugan, "Automatic Carbon, Hydrogen, Nitrogen, Sulfur Analyzer Ciiemistry of Sulfur Reactions," Analytical Letters, vol. 10, pp. 639-657, 1977.
[17] H. Dhawan and D. K. Sharma, "Advances in the chemical leaching (inorgano-leaching), bio-leaching and desulphurisation of coals," International Journal of Coal Science \& Technology, pp. 1-15, 2019.

[18] P. Zhang, S. Zhang, L. Shao, M. Bing, S. Qiu, and Q. Zhang, "Desulfurization of High Sulfur Coal Leached with $\mathrm{H}_{2} \mathrm{O}_{2}$ and $\mathrm{NaOH}$ by Microwave Irradiation," in Applications of Process Engineering Principles in Materials Processing, Energy and Environmental Technologies, ed: Springer, 2017, pp. 259-269.

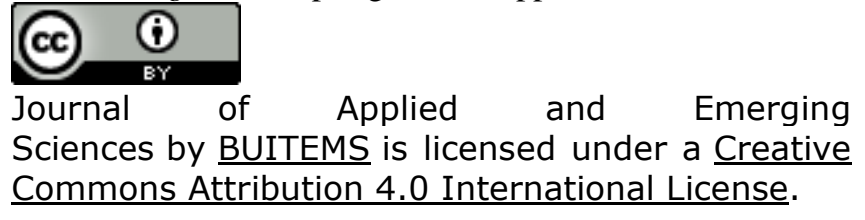

